\title{
artigo A INTERAÇÃO USUÁRIO X JORNAL EM UM SITE DE REDE SOCIAL:

\author{
indícios de uma mudança
}

Copyright (c) 2014 SBPjor / Associação Brasileira de

Pesquisadores em Jornalismo
MABEL OLIVEIRA TEIXEIRA

Universidade Católica de Pelotas

\begin{abstract}
RESUMO - O presente artigo visa estabelecer uma discussão acerca da relação entre usuário x jornal no ciberespaço ou, mais especificamente, na ferramenta de Comunicação Mediada por Computador (CMC), o site de rede social (SRS) Facebook. Para estabelecer tal discussão, este trabalho partiu à exploração das interações entre usuários do Facebook e um veículo jornalístico de expressão nacional, a Folha de São Paulo (FSP), através dos procedimentos metodológicos defendidos pela Teoria Fundamentada ou Fundada (TF). Sendo assim, realizou-se a coleta manual de uma notícia divulgada pela FSP no Facebook e dos 207 comentários que a seguiram. A análise e sistematização dos dados serviu à consolidação do debate pretendido e à indicação de mudanças sociais que deslocam o jornalismo de sua posição de como organizador legitimado da própria experiência humana. Palavras-chave: Teoria Fundamentada. Sites de rede social. Ciberespaço. Webjornalismo.
\end{abstract}

\section{LA INTERACCIÓN USUARIO X PERIÓDICO EN UN SITIO DE REDES SOCIALES: evidencia de un posible cambio en la relación}

RESUMEN - Este artículo tiene como objetivo establecer una discusión sobre la relación entre usuario $\mathrm{x}$ periódico en el ciberespacio o, más específicamente, en la herramienta de comunicación mediada por computadora (CMC), el sitio de redes sociales (SNS) Facebook. Para establecer este debate, el presente trabajo se rompió la exploración de las interacciones entre los usuarios de Facebook y un periódico nacional, la Folha de São Paulo (FSP ), a través de procedimientos metodológicos defendidos por la Teoría Fundamentada ( TF). Por lo tanto, siguieron la recolección manual de un informe de noticias de FSP en Facebook y sus 207 comentarios. Análisis y sistematización de los datos sirvieron para consolidar el debate indicación prevista y los cambios sociales que desplazan el periodismo legitimó su puesto como organizadora de la experiencia humana.

Palabras clave: Teoría Fundamentada. Redes sociales. Ciberespacio. Webjournalism.

\section{USER X NEWSPAPER INTERACTION ON A SOCIAL NETWORK SITE: evidence of change}

\begin{abstract}
This paper aims to establish a discussion of the relationship between users $\mathrm{x}$ newspapers in cyberspace or, more specifically, in a Computer Mediated Communication Tool (CMC), the social networking site (SNS) Facebook. To establish the discussion proposed, this paper broke for exploration of interactions between users of Facebook and a newspaper of national expression, the Folha de São Paulo (FSP), through methodological procedures advocated by Grounded Theory (TF). Thus, there was the manual collection of a news report published by FSP on Facebook and of the 207 comments that followed. The analysis and systematization of data served to consolidate the intended debate and the social changes that shift the journalism position as the organizer legitimate of human experience.
\end{abstract}

Keywords: Grounded Theory. Social networking. Cyberspace. Webjournalism. 


\section{APRESENTAÇÃO METODOLÓGICA: UMA APROXIMAÇÃO COM O CAMPO}

O presente artigo presta-se à investigação das interações estabelecidas entre usuários de um site de rede social (SRS) ${ }^{1}$ e um veículo jornalístico. Para tanto, recorre-se ao método da Teoria Fundamentada ou Fundada (TF), uma vez que tem se mostrado profícuo às recentes investidas da pesquisa social no ambiente ciberespacial. Conforme indicam Recuero, Fragoso e Amaral (2011 , p. 87), a TF é "[...] particularmente interessante aos dados obtidos em um campo onde ainda há uma profusão de dados para coleta e ainda um pequeno corpo teórico, como é o caso dos fenômenos do ciberespaço".

Proposta por Glasser e Strauss na obra The Discovery of Grounded Theory, de 1967, a TF pretende uma coleta sistemática de dados e, ao mesmo tempo, a constante comparação e análise dos dados obtidos pelo pesquisador. Sendo assim, o método garante a centralidade do pesquisador durante o processo de pesquisa já que é a partir da percepção subjetiva deste que os dados devem ser extraídos e significados. Em suma, pode-se dizer que a principal característica da TF está na subversão da ordem científica tradicional. Em sua perspectiva, "[...] é o campo e sua observação que vai fornecer as hipóteses e auxiliar a delimitar o problema e construir a teorização. Os dados, assim, atuam de modo fundamental no processo" (RECUERO; FRAGOSO; AMARAL, 2011 , p. 84).

Dito isso, destaca-se que este estudo não será iniciado pela exposição de um referencial teórico alienado do trabalho de campo, mas exatamente pela apresentação e exploração do ambiente de onde os dados são extraídos e que, ao mesmo tempo, representa o universo conceitual que circunda o objeto a ser observado, garantindo sua contextualização.

Deve-se dizer, portanto, que o presente artigo está focado na observação, sistematização e análise dos dados extraídos do objeto de pesquisa selecionado. Assim, não se pretende impor qualquer tipo de generalização acerca do relacionamento entre usuários do Facebook e veículos de mídia. Todos os apontamentos que venham a ser feitos serão, dessa forma, indicações cujo alcance estará limitado pelo corpus de análise não representando, necessariamente, a natureza majoritária das interações entre usuários e veículos midiáticos.

Feitas tais ressalvas, cabe expor, primeiramente, que o artigo irá trabalhar com dados retirados de um popular site de rede social, o Facebook, ou, mais especificamente, com uma publicação do jornal Folha de S. Paulo (FSP), realizada em 30 de janeiro de 2012 , em seu perfil ${ }^{2}$ no sistema. Ressaltase que a exposição de apenas uma publicação dá-se em função da limitação 
de espaço, todavia, destaca-se que a matéria selecionada faz parte de um corpus composto por 50 publicações da FSP, todas extraídas entre janeiro e setembro de 2012. Essas postagens ${ }^{3}$ constituem o corpus de um estudo maior que reunirá as análises de cada uma das 50 publicações a fim de aprofundar a discussão que será exposta no presente trabalho.

Lançado em 2004, o Facebook é, atualmente, o SRS com o maior número de usuários cadastrados, ultrapassando a marca de 1 bilhão de perfis ativos, conforme dados divulgados pelo site UOL, em agosto de 2012. O crescente número de usuários de SRSs e a hodierna transformação de tais ambientes em verdadeiros círculos de troca voltados à manutenção e ao estabelecimento de laços sociais ${ }^{4}$ são indícios das alterações ocasionadas pela constante mediação tecnológica.

Por definição, um site de rede social é um espaço que permite aos indivíduos algumas ações básicas que, segundo Boyd e Ellison (2007), podem ser resumidas em: a criação de perfis, a interação entre todos os indivíduos que constituem tal rede (usuários) e a publicização da lista de contatos de cada um, deixando visíveis as conexões estabelecidas entre os usuários. Assim sendo, os SRSs não devem ser considerados como a rede social em si, mas sim como os sistemas que suportam tal rede.

Uma rede social pode, portanto, ser resumidamente compreendida como um conjunto de atores sociais e suas conexões. Tais conexões são compostas pelas interações e trocas estabelecidas entre os atores, ressaltandose que a volatilidade inerente às interações humanas confere o caráter dinâmico das redes sociais (RECUERO, 2009a). Sendo assim, os SRSs representam,

[...] espaços de lazer, lugares virtuais onde as práticas sociais
começam a acontecer, seja por limitações do espaço físico, seja
por limitações da vida moderna, seja apenas pela comodidade da
interação sem face. Tratam-se de novas formas de "ser" social que
possuem impactos variados na sociedade contemporânea a partir
das práticas estabelecidas no ciberespaço [...] As características
dos sites de rede social, nesse contexto, acabam gerando uma
nova "forma" conversacional, mais pública, mais coletiva, que
chamaremos de conversação em rede (RECUERO, 2012, p. 16-17).

Nesse sentido, o crescimento dos sistemas que suportam tal conversação, possibilitados pelo aparecimento da $\mathrm{Web}^{5}$, representa a atual prevalência do modelo de comunicação todos-todos (LÉVY, 1999) e evidencia uma tendência à democratização dos espaços virtuais de publicização e dos meios de produção de conteúdo, estimulando uma incessante reverberação da conversação em rede (TEIXEIRA, 2011; LEMOS, 2004; RECUERO, 2012).

Essa conversação é, assim, um dos reflexos da liberação do polo emissor (LEMOS, 2004) e o elemento-chave para o aparecimento de 
fenômenos culturais típicos da sociedade atual como, por exemplo, os memes $^{6}$, os flash mobs ${ }^{7}$, os protestos on-line etc. Ao se discutir os processos ocorridos em um SRS, não se está, portanto, travando uma batalha acerca das possibilidades técnicas surgidas junto aos equipamentos eletrônicos e digitais, mas sim abrindo espaço à discussão dos processos socioculturais que formatam a chamada "era da informação" (CASTELLS, 2010) e a "cultura da convergência" (JENKINS, 2009).

O campo de estudo delimitado neste trabalho - o SRS Facebook -, tem o funcionamento baseado no modelo "Círculo de Amigos", desenvolvido pelo cientista britânico Jonathan Bishop (BOYD; ELLISON, 2007). Tal modelo visa à construção de perfis que se interconectam, dando origem a uma rede social que será mantida pelo próprio sistema. Nesse cenário, cada usuário ou ator da rede tem acesso a um grande número de recursos voltados à interação com os demais: os comentários, as publicações, as curtidas, a criação de eventos e a adesão aos módulos de aplicativos (ferramentas, jogos sociais etc.) que podem ser criados pelos próprios usuários.

Concentrando 62,06\% dos brasileiros usuários de SRSs, segundo pesquisa divulgada pelo Experian Hitwise ${ }^{8}$, o Facebook tem chamado a atenção de grandes empresas jornalísticas nacionais que estão a utilizando a ferramenta tanto para divulgar ações, publicar e fazer circular conteúdos como para interagir de forma mais direta com seu público (ZAGO, 2011 ; TEIXEIRA, 2011).

Conforme exposto anteriormente, elegeu-se trabalhar com 0 jornal Folha de S. Paulo (FSP) ${ }^{9}$. Essa escolha justifica-se não apenas pela expressividade daFSP no cenáriojornalístico ${ }^{10}$ brasileiro, mas, principalmente, pelo caráter vanguardista assumido dentro do ciberespaço ao ser o primeiro veículo nacional a lançar um site de notícia em tempo real, o que ocorreu em 1995. Quinze anos depois, a Folha seria um dos primeiros veículos de mídia a ingressar no Facebook. Atualmente, a importância da página da FSP no sistema pode ser mensurada pelo grande número de "curtidas" recebidas, que ultrapassam a marca de 1 milhão, e pela estimativa de reverberações ${ }^{11}$ de seus conteúdos, cerca de 155.433 interações registradas.

É preciso salientar que, uma vez que as interações selecionadas são oriundas de uma ferramenta de CMC (Comunicação Mediada por Computador), esta pesquisa não pode ignorar as características específicas do ambiente ciberespacial e sua influência nas relações estabelecidas na Rede ${ }^{12}$. Assim, conforme impõe o método de análise adotado, as conexões e abordagens teóricas serão postas conforme o que a observação e a sistematização do corpus venham a exigir.

Deve-se, com isso, ressaltar que a imersão no campo foi o 
primeiro passo desta pesquisa, seguido pela coleta, sistematização e discussão do universo revelado por intermédio dos dados. Todavia, não se partiu ao campo sem nenhuma ideia prévia dos possíveis resultados, uma vez que o objetivo do trabalho já estava focado, de antemão, na compreensão da relação usuário x jornal dentro de um SRS. Dito isso, parte-se à apresentação e sistematização dos dados.

\section{1 (RE)CONHECENDO OS DADOS: DEFINIÇÃO DO CORPUS}

A coleta dos dados, realizada no dia 19 de fevereiro de 2012, deu-se por meio da seleção manual de uma notícia publicada na página da FSP no Facebook, no dia 30 de janeiro de 2012. A matéria selecionada para este estudo centra-se na exploração dos desdobramentos de um fato noticioso amplamente retratado nos veículos de mídia brasileiros: o incêndio da Boate Kiss ocorrido na madrugada do dia 27 janeiro de 2012, na cidade de Santa Maria (RS).

Assim, destaca-se que a notícia selecionada para este estudo foi definida no dia de sua publicação, 30 de janeiro de 2012, mas seu monitoramento só foi encerrado no dia 19 de fevereiro, totalizando 21 dias entre a postagem da matéria e o fim do monitoramento. Durante esse período, foram coletados todos os comentários acrescidos à publicação da FSP, totalizando 207 interações.

Destarte, consideram-se como dados, sujeitos à análise, cada um dos comentários acrescidos à publicação da FSP, bem como o texto e a imagem que a constituem. Destaca-se que os comentários tecidos pelos usuários foram considerados como mecanismos de interação em função do caráter dialógico que estabelecem com o próprio fato, com a notícia em si, com seu autor (o jornal FSP), com os personagens que orbitam o acontecimento e, ao mesmo tempo, com os outros usuários.

Figura 1 Notícia

Fouma Folha de S.Paulo

Vítima do incêndio na boate Kiss se comunica com a família por bilhete. http://folha.com/no1222763 Ana Carolina Soares da Costa, 18, sofreu queimaduras e respira com a ajuda de aparelhos.

Fonte: Página da FSP no Facebook 
Conforme se observa na Figura 1, a notícia publicada pela Folha de S. Paulo aparece abaixo dos elementos de identificação do emissor da mensagem - foto do usuário (logotipo da Folha) e nome do usuário (Folha de S. Paulo) -, elemento de indicação temporal (30 de janeiro) e, por fim, do elemento de indicação de restrição da publicação ${ }^{13}$, no caso, o ícone do globo que indica que a mensagem é pública ${ }^{14}$, ou seja, pode ser lida por qualquer outro usuário do Facebook.

Figura 2 Bilhete que ilustra a notícia e os mecanismos de interação

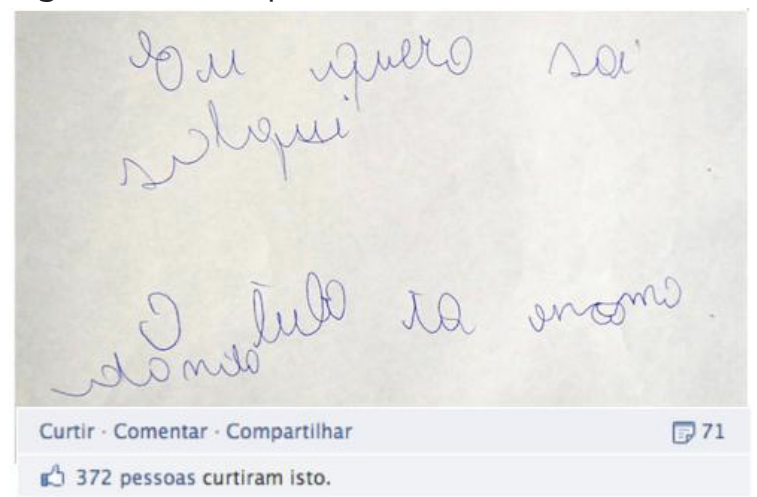

Fonte: Site da FSP no Facebook

Conforme se vê nas Figuras 1 e 2, a notícia selecionada para este artigo possui três dimensões básicas que devem ser observadas, a saber: o texto, a imagem e as interações. A primeira dimensão, o texto da FSP (Figura 1), divide-se em uma frase inicial, que funciona quase como um chamado à observação da imagem do bilhete, e uma frase final, que parece atuar como legenda à imagem. O link presente no texto leva à página da Folha de S. Paulo na Web (Folha.com) e, provavelmente, induz a uma exploração mais detalhada do fato.

Todavia, o conteúdo da página da FSP é restrito e de acesso exclusivo aos assinantes do veículo. Sendo assim, pode-se dizer que a publicação do jornal no Facebook parece funcionar como uma síntese capaz de instigar os leitores a não apenas seguirem o link que leva à página da Folha.com mas também, em função da restrição de acesso ao conteúdo do site, a se tornarem assinantes do jornal.

A segunda dimensão da notícia em questão, ou seja, a imagem (foto do bilhete), é a informação jornalística em si. Compreende-se, portanto, que o fato explorado pela matéria é a própria existência do bilhete, uma vez que sua autora é uma sobrevivente da tragédia 
ocorrida na boate Kiss. A relevância do bilhete apresentado não está, assim, ligada ao seu conteúdo, mas essencialmente à autoria e às circunstâncias nas quais ele foi redigido.

Por fim, o terceiro elemento básico da notícia observada - as interações - tornou-se o aspecto mais profícuo aos propósitos deste estudo. Conforme mostra a Figura 2, a notícia em questão obteve 71 compartilhamentos (outros usuários compartilharam o conteúdo divulgado em suas próprias páginas no sistema), 372 curtidas e um total de 207 comentários. Serão exatamente esses 207 comentários que estarão no cerne da discussão proposta no ponto subsequente. São eles que representam, mais nitidamente, o conteúdo e o tipo de interação que se estabelece entre o material noticioso de um veículo midiático consolidado (FSP) e os usuários do SRS Facebook.

Antes da análise e sistematização dos dados, deve-se ressaltar que com a recente incorporação dos SRS à rotina dos principais veículos de mídia e, consequentemente, ao complexo processo de produção, distribuição e circulação da notícia - os jornalistas começaram a buscar maneiras de se familiarizar com o ambiente e com os processos que formatam as redes sociais na internet (ZAGO, 201 1; TEIXEIRA, 2011 ; CASTELLS, 2006).

Nessa perspectiva, o principal aspecto a ser considerado no contexto dos SRSs é que a atuação dos usuários tem impacto significativo na difusão das informações, pois "o espalhamento da notícia e a leitura do conteúdo jornalístico dependem diretamente da atividade anônima desses usuários interconectados" (BASTOS; ZAGO, 2013, p. 118). Assim, ao utilizarem as redes sociais para distribuir suas notícias, os jornais não apenas proveem o acesso a seus conteúdos como também possibilitam a contribuição dos demais usuários para repercutir o material (ZAGO, 2011), seja por meio de compartilhamentos, seja pelas curtidas e/ou comentários sobre os acontecimentos. Diante dessa realidade, os usuários dos SRSs tornam-se (co)responsáveis pelo espalhamento das informações (JENKINS; FORD; GREEN, 2013) tanto dentro do sistema de origem como fora, em outros ambientes. Conforme indicam Bastos e Zago (2013, p. 119),

[...] a atividades dos usuários que "curtem" ou "retuitam" determinada notícia permite que o conteúdo seja exibido para os contatos desses usuários. Essa replicação confere visibilidade às notícias, que passam a receber mais atenção e uma maior audiência, refletida em termos de leitura e acesso.

Dessa maneira, pode-se dizer que o caráter participativo e colaborativo (LEMOS; LÉVY, 2010) dos SRSs estimula a distribuição de informação entre usuários, entre redes e sub-redes em efeito cascata 
(RECUERO, 2009b), ou seja, os conteúdos passam a ser difundidos de maneira "viral", passando de um grupo a outro. Em função da influência dos SRSs na atividade jornalística contemporânea, estudos recentes têm abordado com certa frequência a relação entre jornalismo e redes sociais na internet (BRUNO, 201 1; BRUNS; HIGHFIELD, 2012; ZAGO, 2011 ; DALMASO, 2012; TEIXEIRA, 2011 ; HERMIDA, 2012; JÚNIOR, 2013; VIS, 2012; PRIMO, 2011 ).

Todavia, grande parte dessas pesquisas centra-se no tipo de conteúdo jornalístico compartilhado ou no movimento das redes sociais que, por meio dos sites, blogs, fóruns etc., constituem fontes alternativas de informação, imprimindo um caráter mais horizontalizado ao processo comunicacional. São poucos, portanto, os trabalhos focados no relacionamento direto entre jornais e usuários nos SRSs e em suas possíveis significações. Será sobre esse fenômeno que abrange o relacionamento entre jornais e usuários, ainda pouco explorado e em plena efervescência, que o presente estudo almeja refletir.

\section{APRECIAÇÃO E ORGANIZAÇÃO DOS DADOS COLETADOS}

Após uma observação inicial dos 207 comentários coletados, fez-se necessário, em função da orientação metodológica adotada, a sistematização/categorização desse material, o critério adotado para realizar tal tarefa foi o conteúdo dos comentários. Dessa forma, buscaramse similaridades nos comentários selecionados a partir da análise do que foi dito pelos usuários e do modo pelo qual foi expresso. Tal análise levou a uma classificação que pode ser observada na Tabela 1.

Tabela 1 Classificação e ocorrência das categorias

\begin{tabular}{lc}
\hline Natureza dos Comentários & Ocorrência \\
\hline Crítica ao jornal e/ou ao relato noticioso & 61 \\
\hline Apoio ao jornal e/ou legitimação da notícia & 04 \\
\hline Crítica entre usuários & 84 \\
\hline Colaboração & 12 \\
\hline Solidariedade & 38 \\
\hline Sátiras & 11 \\
\hline Outros & 09 \\
\hline
\end{tabular}

Fonte: Produção original

Cabe esclarecer que a soma do número de ocorrências das 
categorias apresentada na Tabela 1 ultrapassa o total de 207 comentários em função de alguns serem alocados em mais de uma categoria. Nesse sentido, o conteúdo das mensagens e a postura assumida pelos usuários mediante as suas falas, levou, conforme indicado, à distinção de 7 categorias, a saber: (1) crítica ao jornal e/ou ao relato noticioso; (2) apoio ao jornal e/ou legitimação da notícia; (3) crítica a outros usuários; (4) colaboração; (5) solidariedade; (6) sátira; e (7) outros.

A primeira categoria a ser descrita será a que apresenta o maior número de ocorrências, ou seja, aquela que reúne as críticas entre usuários. Desse modo, foram encontrados 84 comentários voltados à depreciação de outro comentário e/ou de seu autor. É importante ressaltar que os comentários são postos, pelo próprio sistema do Facebook, logo abaixo da publicação original, obedecendo à ordem cronológica de suas publicações. O sistema também permite que cada usuário receba uma notificação quando um novo comentário for adicionado a um tópico sobre o qual o usuário já tenha se manifestado e/ou quando outro usuário o mencionar em uma postagem.

A Figura 3 traz exemplos de críticas (comentários 23, 65, 68) direcionadas ao autor e ao conteúdo do comentário 1 (primeira interação entre um usuário e o material da FSP). Note-se que não há qualquer referência ao material informativo nos comentários 23, 65 e 68, postos como exemplos. Assim, eles deixam de atuar como comentários do tópico de origem para tornarem-se um diálogo paralelo entre usuários. Com base nessa categoria, percebe-se que a ferramenta comentário deixa de funcionar conforme o sistema previa e passa, em função da apropriação dos usuários, a ter uma função ligada à conversação.

Figura 3 Foto da notícia e mecanismos de interação às publicações do Facebook

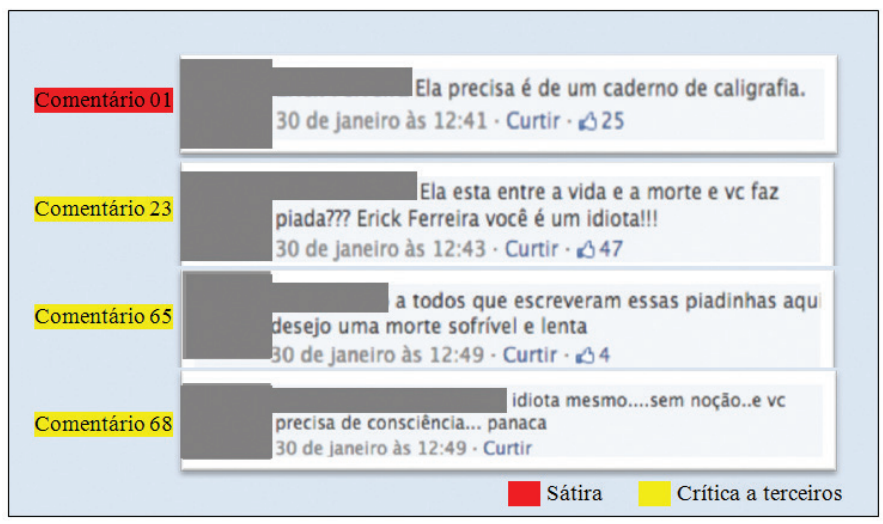

Fonte: Página da FSP no Facebook 
Segundo Recuero (2012), é exatamente essa conversação que se configura como a principal forma de comunicação mediada por computador (CMC) que, por sua vez, é um produto da apropriação social das ferramentas de CMC. A apropriação, assim, é o resultado das ressignificações construídas pelos atores quando dão sentido a tais ferramentas em seu cotidiano. Dessa maneira pode-se dizer que a CMC,

[...] compreende práticas conversacionais demarcadas pelas trocas entre atores sociais. Suas características advêm, deste modo, também da apropriação das ferramentas digitais como ambientes conversacionais. Examinar essas conversações, portanto, é essencial para que se compreenda também as mudanças na linguagem e nos grupos sociais que emergem nesses espaços (RECUERO, 2012, p. 27).

Dito isso, parte-se para a observação do primeiro comentário (Figura 3) que, por sua vez, foi alocado em uma segunda categoria, a saber: a sátira. Embora essa categoria tenha reunido apenas 11 comentários, ela mostrou ter grande influência na produção e no conteúdo dos comentários subsequentes. A esse respeito, foram considerados como exemplos desse tipo de interação os comentários jocosos e satíricos acerca do bilhete apresentado como fato noticioso e/ou acerca dos outros usuários e suas declarações. Nessa situação, é evidente o tom agressivo dos comentários voltados a repreender os autores desse tipo de comentário, tal reação parece delimitar a fronteira invisível do que pode ou não ser dito naquele espaço em função de todo o contexto de comoção social em que orbita o fato noticioso em questão.

Importante salientar que não há, no corpus, qualquer interferência ou repreensão por parte da FSP. Desse modo, todas as possíveis limitações e os ordenamentos são definidos e expostos pelos demais usuários que comentam no perfil do jornal. Face ao exposto, André Lemos e Pierre Lévy (2010) afirmam que o insulto e o desprezo costumam ser malvistos na conversação em rede,

\footnotetext{
Cada um é obrigado a saber daquilo que se fala e se comportar bem. O menor movimento de humor é aparente no nosso estilo, como nossa maneira de nos dirigir aos interlocutores. Qualquer que seja o nosso status, não temos mais o direito de desqualificar o problema ou a questão do outro. A Internet nos civiliza: o outro se aproxima de nós no nó da linguagem (LEMOS; LÉVY, 2010, p. 232-233).
}

Acordando com os apontamentos dos autores, a terceira categoria extraída dos comentários analisados foi a de mensagens de solidariedade. Nesse grupo, foram reunidos os comentários cujo conteúdo volta-se à expressão de sentimentos de comoção e solidariedade pela situação da autora do bilhete, das famílias das vítimas e/ou pela ocorrência 
da tragédia. Destaca-se que, dos 38 representantes de tal categoria, a maior parte visa transmitir mensagens de esperança aos familiares e aos sobreviventes da tragédia, conforme se pode observar na Figura 4. Tais mensagens evidenciam o clima de comoção pública que foi estendido ao ciberespaço e, consequentemente, às redes sociais que suporta.

Figura 4 Comentários de solidariedade (exemplar 114)

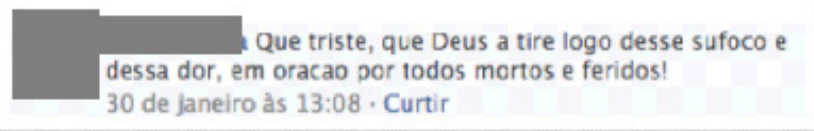

Fonte: Página da FSP no Facebook

A quarta categoria observada, outros, reúne 9 comentários cujo conteúdo oscila entre a divulgação de links externos ${ }^{15}$ e o registro de expressões emocionais com o uso de emoticons ${ }^{16}$ que se integram ora ao debate entre os usuários, ora ao conteúdo da notícia. Evidencia-se que os exemplares de tal categoria poderiam, não fosse o espaço restrito, ser analisados mais detalhadamente, uma vez que indicam um fenômeno interessante por meio do qual os usuários da rede beneficiam-se do capital social ${ }^{17}$ de um elemento muito conectado (nó com muitas conexões), a FSP, para divulgarem material pessoal como o endereço de seus sites, blogs ou perfis em outras redes.

Outra categoria detectada durante a análise, a colaboração ${ }^{18}$, prestouse a alocar os comentários voltados a uma ação colaborativa, seja voltada a outro usuário seja voltada ao próprio conteúdo noticioso. Neste trabalho, também se consideraram questionamentos acerca do fato noticioso como ações colaborativas. Com 12 exemplares dessa categoria detectados no corpus, foi possível notar que parece haver, no Facebook, maior liberdade à interferência e contribuição com o relato noticioso e com o processo de compreensão/ significação do fato. Diz-se isso porque boa parte dos exemplares dessa categoria volta-se a transcrever o conteúdo do bilhete ou a expor o contexto de sua produção. A Figura 5 apresenta exemplos de colaboração:

Figura 5 Comentários de colaboração (respectivamente exemplar 170 e 195)

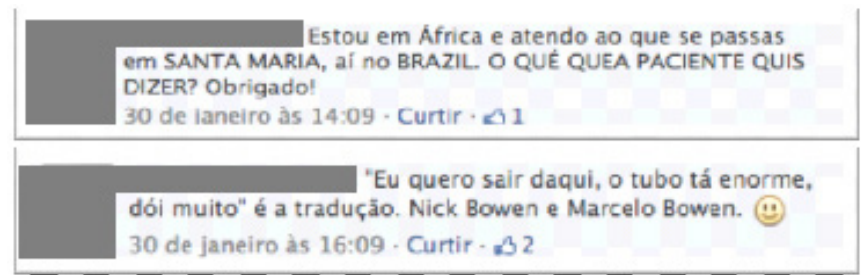

Fonte: Página da FSP no Facebook 
A quinta categoria a ser mencionada concentra os comentários de apoio ou legitimação do fato noticioso. Essa categoria chama especial atenção por revelar uma posição, assumida pelos usuários, por meio da qual eles tomam para si o poder/conhecimento do que deve ser considerado notícia e os limites entre fatos noticiáveis e não noticiáveis. No exemplo subsequente, Figura 6, vê-se que o usuário coloca seu interesse no estado das vítimas do incêndio como fator legitimador à publicação e postulação do relato como notícia.

Figura 6 Comentários de apoio/legitimação (exemplar 97)

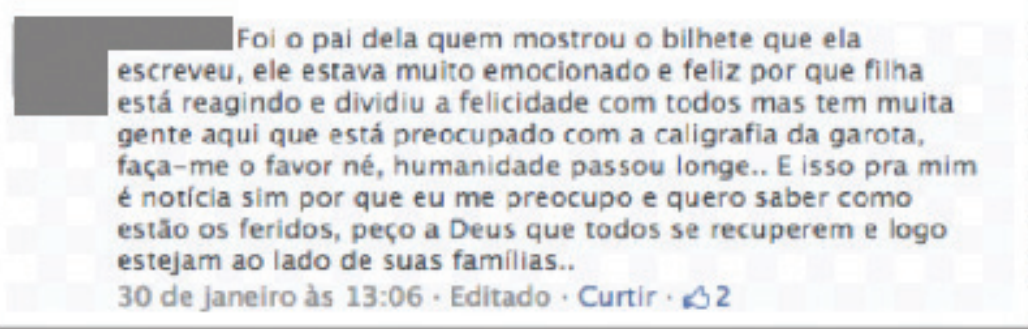

Fonte: Página da FSP no Facebook

Deve-se evidenciar que essa postura legitimadora, encontrada em 4 comentários, surge como resposta às críticas de outros usuários ao material publicado pelo jornal. Estas, por sua vez, formatam a última categoria detectada durante análise e a segunda mais numerosa, a saber: a crítica ao jornal e/ou ao relato noticioso.

Ao certo, essas duas últimas categorias são as mais profícuas à proposta de análise do relacionamento entre usuários e os veículos de comunicação - no caso, o jornal FSP - no SRS Facebook, pois seus objetos demonstram, com maior clareza, a interação dos usuários com o veículo/conteúdo. Assim sendo, o presente estudo centrar-se-á com maior diligência à exposição das idiossincrasias da categoria "comentários de apoio ou legitimação" e, especialmente, da categoria crítica ao jornal e/ou ao relato noticioso.

Antes, sobretudo, faz-se necessário apresentar a reorganização das categorias que, após um segundo olhar, foram distribuídas em grupos que se diferenciam pela dinâmica da interação. O resultado obtido pode ser apreciado, resumidamente, por meio da observação da Tabela 2: 
Tabela 2 Classificação das categorias em função do tipo de interação e suas ocorrências

\begin{tabular}{l|c|l}
\hline Interação & Ocorrência & \multicolumn{1}{c}{ Categorias dos Comentários } \\
\hline Usuário x Jornal & 65 & $\begin{array}{l}\text { Crítica ao jornal e/ou ao relato noticioso, } \\
\text { Apoio ao jornal ou legitimação da notícia. }\end{array}$ \\
\hline Usuário x Usuário & 84 & Crítica a terceiros. \\
\hline Variada & 70 & Colaboração, Solidariedade, Sátira e Outros. \\
\hline
\end{tabular}

Fonte: Produção original com base na análise dos dados

A distribuiçãa das categorias, apontada pela Tabela 2, tornase relevante, uma vez que indica quais categorias concentram os comentários direcionados especificamente ao jornal ou ao conteúdo publicado por ele. Crê-se, portanto, que o conjunto dos 65 comentários voltados à FSP sejam os dados mais profícuos à compreensão da relação entre usuário x jornal. Dessa forma, o ponto seguinte trará a discussão dos dados indicados e as contextualizações teóricas necessárias ao reconhecimento do fenômeno que pode estar, paulatinamente, alterando o relacionamento dos usuários de "redes sociais" com o "jornalismo".

\section{DISCUTINDO COM OS DADOS: A INTERAÇÃO USUÁRIO x JORNAL}

Com o aparecimento das ferramentas de CMC e, principalmente, do ciberespaço, houve uma gradual democratização dos espaços de fala e, ao mesmo tempo, o estabelecimento crescente de espaços constituídos por um fluxo contínuo de troca de informações entre pessoas conectadas como o são, por exemplo, os SRSs (LÉVY, 1999; LEMOS, 2004). Tais ferramentas alteram os processos de comunicação, de produção, de criação e de circulação de bens e serviços no início do século XXI, trazendo uma nova configuração de todo sistema cultural (LEMOS, 2005). Uma das características essenciais dessa nova formatação é, segundo Lemos, a liberação do polo de emissão, fator que afeta diretamente a esfera jornalística já que, na Web, cada um pode tornar-se "[...] produtor de informação (um jornalista, no sentido essencial da palavra), em jornalista de si, mas também de tudo aquilo que é possível testemunhar com smartphones, palm ou laptop nas mãos" (LEMOS; LÉVY, 2010, p. 82).

Assim, quando se observa, no grupo de comentários direcionados a interagir com o jornal, o abismo entre o número de comentários voltados a legitimar o relato noticioso da FSP (04) e o número de críticas direcionadas ao veículo (61), representado por 
meio da Figura 7, deve-se ter em mente que o atual contexto social não se mostra tão receptivo à mediação dos veículos de comunicação e à dinâmica homogeneizante dos chamados Meios de Comunicação de Massa (MCM). Em suma, pode-se dizer que "o fenômeno das mídias sociais e da geração de conteúdo pelos usuários reconfigura as relações entre amadores e a indústria das mídias e suas instituições oficiais" (DOMINGUES, 2010, p. 68).

Figura 7 Gráfico: ocorrência das categorias de comentários na interação usuário x jornal

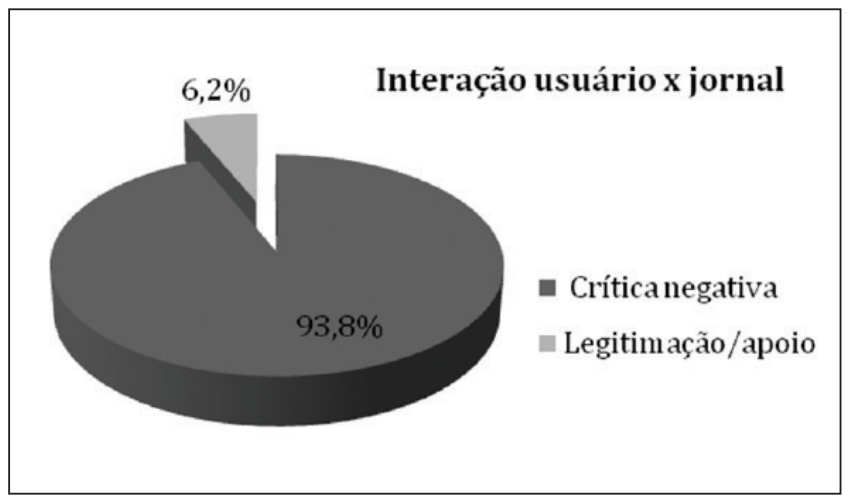

Fonte: Produção original com base na análise dos dados

Na Figura 8, exposta a seguir, pode-se perceber a marcação de um posicionamento crítico e provocador na fala dos usuários. Tal fato evidencia o já citado espírito indagador dos usuários com relação ao que deve ou não ser considerado notícia e, portanto, publicado por um veículo de comunicação. Embora os comentários dados possam não chamar imediata atenção, eles revelam um fenômeno social que está, potencialmente, afetando o modo de se fazer jornalismo.

Diz-se isso, pois, na perspectiva da teoria democrática, o jornalismo é reconhecido como um campo $^{19}$ ou esfera de atividade específica constituída por "agentes especializados", os jornalistas, que possuem o monopólio de saberes/conhecimentos idiossincráticos (o que são as notícias e como produzi-las) (TRAQUINA, 2005, 2008). Contudo, tal monopólio só pode ser mantido por meio da legitimação social da atividade jornalística como "organizadora" do caos informativo e da própria experiência humana (SCHUDSON, 1988, 1995). 
Figura 8 Crítica ao jornal e/ou relato noticioso (respectivamente exemplares 113, 202)

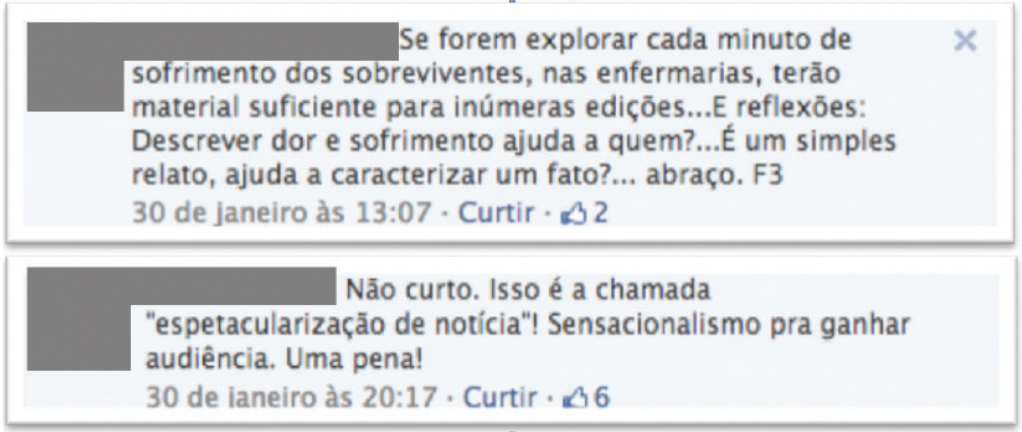

Fonte: Página da FSP no Facebook

Os comentários dados indicam a sensação de incerteza dos usuários com relação à capacidade dos "agentes especializados" de filtrar os fatos que devem ser postos como notícia. Sabe-se que, ao longo do processo histórico, a compreensão do que é ou não notícia foi alterada em função de mudanças sociais e culturais de uma dada comunidade (PENA, 2006). Todavia, desde sua consolidação como um campo profissional, no final do século XIX, raras foram as ameaças ao papel privilegiado do jornalismo. Ele deteve não apenas o conhecimento, mas também os meios necessários à produção e distribuição das informações (O’BOYLE, 1968; TRAQUINA, 2005).

Atualmente, não se pode mais pensar no público/leitor como mero receptor da informação produzida por grandes veículos de mídia. Além do fácil acesso a conteúdos alternativos e da possibilidade de criar, editar e publicar as informações que deseja, o "público" de hoje se sente à vontade para assumir a posição de crítico do conteúdo noticioso, filtrando e estabelecendo limites à atuação do jornalismo. O exemplo abaixo (Figura 9) deixa evidente que os usuários dos SRSs parecem possuir consciência acerca de seu poder de barganha sobre os veículos de mídia tradicional. Se, no sistema cultural dos MCM, a sociedade precisava do jornalismo para conhecer a própria realidade (PENA, 2006), hoje, com as ferramentas de CMC, o jornalismo tornou-se apenas uma entre tantas outras fontes de informação. 
Figura 9 Crítica ao jornal e/ou relato noticioso (exemplar 131)

tem audiencia, inclusive a virtual.

a midia existe porque

30 de janeiro às $13: 18$. Curtir

Fonte: Página da FSP no Facebook

Pode-se, então, afirmar que os SRSs ampliaram o sistema de difusão e circulação de informação, levando as tradicionais empresas de mídia a perderem o absoluto controle sobre o processo de produção e circulação da informação. "As redes digitais passaram a ser caracterizadas por um fluxo não linear, que altera significativamente a forma do que se chama de esfera global de notícias" (PRIMO, 2011 , p. 3).

Hoje, os indivíduos não têm mais os veículos tradicionais como única fonte de informação e não depositam total confiança nos relatos da mídia oficial. Desse modo, os usuários estão criando novas estratégias para interagir e buscar conteúdo na rede sem necessitar da constante mediação dos veículos de mídia (PRIMO, 2008). Para tanto, os usuários recorrem às perspectivas diferenciadas presentes nos blogs, nos fóruns ou nos SRSs; a visão de mundo desses usuários emerge, destarte, do cruzamento de todas essas informações que formam seu "composto informacional midiático" (PRIMO, 2011, p. 12).

O tom agressivo dos usuários - observado, especialmente, na categoria de crítica ao jornal - parece apontar a um sentimento de "competitividade" entre os usuários e os veículos jornalísticos presentes na Rede. A observação de tal comportamento leva a considerar que esta "agressividade" é, grosso modo, uma expressão da recente tomada do polo de emissão e, ao mesmo tempo, uma provocação àqueles que por tanto tempo ficaram "imunes” à crítica e/ou à contestação do público. Deve-se destacar que, uma vez realizado e materializado no Facebook, o comportamento provocativo e, por vezes, a rejeição aos veículos jornalísticos está potencialmente representando uma rede de pessoas.

Diz-se isso porque cada ator possui certo nível de influência sobre os demais membros do grupo, podendo, assim, estimular e transmitir o aparecimento de ideias, comportamentos, ações etc. Abaixo segue um exemplo (Figura 10) dessa tentativa de mobilização de uma rede de pessoas (uma rede social) em prol de um objetivo. No caso referido, o usuário estimula os outros a denunciarem ${ }^{20}$ a página da FSP em função do material divulgado ter sido considerado inadequado, segundo ele, por um grande número de usuários. Pode-se dizer que a mensagem transmite, até certo ponto, a potencial inversão na hierarquia tradicional pela qual o 
jornal define o que é notícia e, sendo assim, determina o que a sociedade precisa saber e o que deve considerar importante. No exemplo citado, o usuário não legitima o fato noticiado como notícia e, dessa maneira, busca exercer seu poder mediante a denúncia do conteúdo publicado na expectativa de retirá-lo do site e/ou do seu feed ${ }^{21}$.

Figura 10 Crítica ao jornal e/ou relato noticioso (respectivamente exemplares 188, 189)

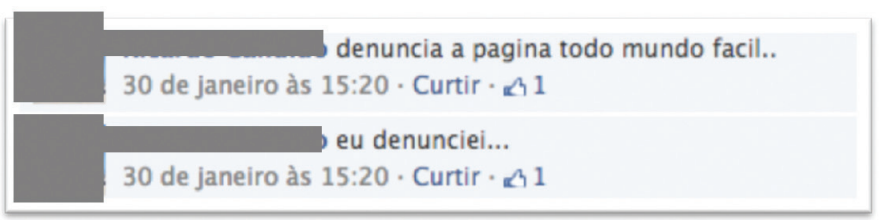

Fonte: Página da FSP no Facebook

Alguns dos 65 comentários classificados como críticas ao jornal demonstram (Figura 11 ) que a incitação à rejeição pode chegar à efetiva exclusão do perfil do veículo da rede de contatos de determinado ator ou à negligência do conteúdo noticioso divulgado pelo jornal. Tornadas ou não ações efetivas, expressões como as citadas indicam certo grau de animosidade entre os usuários e o jornal.

Figura 11 Crítica ao jornal e/ou relato noticioso (respectivamente exemplares 187, 166)

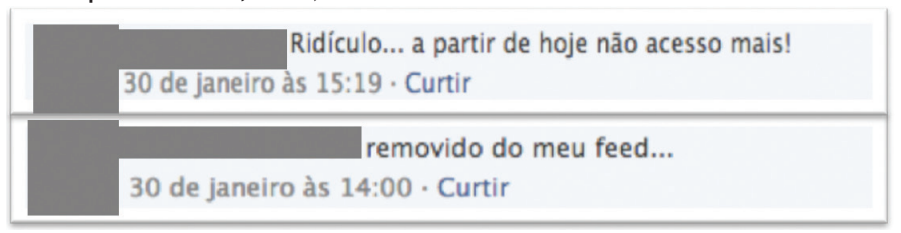

Fonte: Página da FSP no Facebook

De acordo com Recuero (2009b), a discussão a respeito da atividade jornalística passa, hoje, pelo reconhecimento e pela discussão de seu posicionamento diante das redes sociais na internet que, segundo a autora, podem produzir, filtrar e reverberar informações baseadas em percepções específicas de seus membros. Destarte, a autora destaca que as redes podem constituir-se em complementares ao jornalismo, a partir de seu papel de gatewaching, podendo, assim, atuar com um duplo papel informativo definido pela relação entre as redes sociais e o conteúdo jornalístico publicado nas ferramentas de CMC, a saber: (1) como fontes, 
como filtros ou (2) como espaço de reverberação das informações.

A análise dos comentários oriundos da interação usuário $x$ jornal, aqui posta, parece, por sua vez, dar pistas à investigação das redes sociais como fiscalizadoras críticas dos veículos e produtos jornalísticos. Diz-se assim que os usuários, ao exercerem seu poder de fala dentro do SRS, estão, conforme indicações extraídas do corpus, atuando como uma espécie de ombudsman ${ }^{22}$ da atividade jornalística vinculada à Rede.

Se assim se confirmar, em pretensos estudos futuros, o papel de ombudsman poderá postar-se não apenas como o terceiro papel informativo das redes sociais mas também como uma forte evidência de que a típica relação usuário x jornal está se transformando em função, principalmente, da liberação do polo emissor (LEMOS, 2004) e da consequente dissipação do poder da palavra (GOMES, 2000).

É importante destacar que não se pode considerar os indícios aqui apresentados como evidências incontestes de uma mudança na relação entre os atores sociais e os veículos jornalísticos. Este trabalho representa apenas um pequeno recorte de um fenômeno abrangente que não está dado, mas, ao contrário, está em plena efervescência. Com isso, quer-se dizer que os exemplos apresentados ao longo desta discussão devem ser entendidos como pequenas pistas de uma potencial transformação na configuração da relação usuário $x$ jornalismo. Se, conforme visto, as ferramentas de CMC, especialmente os SRSs, colaboram e evidenciam transformações culturais profundas que alteram o comportamento e as relações dos atores/usuários, parece lógico que, sendo uma atividade essencialmente social, o campo jornalístico não ficará imune às mudanças que emergem das redes.

\section{CONSIDERAÇÕES FINAIS}

Ao longo deste artigo, buscou-se traçar um caminho capaz dar pistas de como os usuários estão se relacionando com o jornalismo dentro de um SRS. É evidente que as limitações impostas pelo corpus não permitem que se façam considerações abrangentes, mas, os dados aqui apresentados podem servir como índices de uma mudança latente se cruzados com os apontamentos teóricos que permearam a discussão. Viu-se que dos 207 comentários vinculados à postagem da Folha, 65 mostram-se focados na interação usuário $x$ jornal. Destes, 93,8\% apresentam conteúdo voltado a criticar negativamente o veículo e/ou o material noticioso e apenas 6,2\% perece buscar 
legitimar o relato da FSP. A Tabela 3 apresenta, resumidamente, as sistematizações impostas ao corpus ao longo deste trabalho.

Tabela 3 Sistematização dos dados de pesquisa

\begin{tabular}{l|l|l|c}
\hline Interação & & Categoria dos Comentários & \\
\hline Usuário x Jornal & 65 & Crítica ao jornal e/ou ao relato noticioso & 61 \\
\hline \multirow{2}{*}{ Usuário x Usuário } & 84 & Apoio ao jornal e/ou legitimação da notícia & 04 \\
\hline \multirow{2}{*}{ Variadas } & \multirow{2}{*}{70} & Crítica a terceiros & 84 \\
\cline { 3 - 4 } & \multirow{2}{*}{} & Colaboração & 12 \\
\cline { 3 - 4 } & & Solidariedade & 38 \\
\cline { 3 - 4 } & & Sátira & 11 \\
\cline { 3 - 4 } & & Outros & 09 \\
\hline
\end{tabular}

Fonte: produção original com base na análise dos dados

A disparidade entre o número de comentários destinados a legitimar e o número de comentários destinados a criticar, parece apontar o desgaste da tradicional relação jornal x usuário ou, pelo menos, algumas mudanças no posicionamento e no comportamento do público outrora considerado passivo. Viu-se, através da ancoragem teórica dada por Lemos e Lévy (2010), que os usuários ganharam voz mediante a liberação do polo emissor que fora possibilitada pelo aparecimento da Web e dos mecanismos de CMC.

Isso significa que, atualmente, os usuários de ferramentas como o Facebook partilham o poder que antes estava restrito aos profissionais do campo jornalístico. As pequenas mudanças na relação entre o público das redes e a esfera jornalística podem levar à paulatina liquefação da hierarquia (TEIXEIRA, 2013) que outrora postulou o jornalismo como o quarto poder (TRAQUINA, 2005, 2008), como o portador absoluto da palavra (GOMES, 2000) e inquestionável conhecedor da verdade dos fatos.

Assim sendo, a análise dos dados apresentados parecem corroborar a ideia de que a liberação do polo emissor desloca o campo jornalístico de seu papel tradicional de organizador do caos informativo e de emissor/relator legitimado da realidade social. Tal ideia permeia, de maneira explícita ou implícita, o trabalho de autores como André Lemos (2004), Pierre Lévy (1999), Alex Primo (2011), Nelson Traquina (2008) e Gabriela Zago (2011), uma vez que todos discutem a (re)estruturação do corpo social (sociedade, instituições e processos) em função das novas práticas (mais colaborativas, 
proativas, interativas, conversacionais e plurais) estabelecidas pelos usuários da rede em seus ambientes de troca.

Pode-se dizer que, na era da informação (CASTELLS, 2010), o que se vê é a consolidação de um "sistema pós-mediático" sustentado por uma lógica já "não de pirâmide [como na era dos MCM], mas matricial ou assimétrica, onde múltiplos atores passam a fazer parte do processo comunicacional" (CÁDIMA, 2012, p. 237). Esse novo sistema,

[...] apela, de facto, a um novo tipo de jornalismo fortemente colaborativo, assimétrico - entre fontes, jornalistas e produsers (sic) - mas cuja hibridez terá necessariamente que recusar as engenharias de compromisso que têm manietado os media, devolvendo-os agora à experiência social, às folksonomies, da cultura das redes e a novas formas emergentes de produzir, editar e distribuir informações que já são uma realidade irreversível (CÁDIMA, 2012, p. 251).

Vê-se, com base nos resultados obtidos pela análise e pelo seu cruzamento com as referências dadas, que o cidadão pósmediático não aceita, pelo menos não sem relutância, as hierarquias verticalizadas que garantiam ao jornalismo certa imunidade a questionamentos e críticas. O público do jornalismo atual está cada dia mais familiarizado à horizontalização das relações, à discussão pública, à ação colaborativa, à construção coletiva do conhecimento e à assunção de um posicionamento crítico, principalmente, com relação às esferas de poder, como a dos media.

Em tal contexto, as redes sociais não parecem compreender a notícia jornalística como verdade incontestável, mas apenas como uma das versões que flutuam em uma rede de relatos que se cruzam, chocam e, por vezes, complementam-se. Se outrora o jornalismo foi considerado o fiscal social dos poderes constituídos, atualmente, ele passa - como instituição firmada - a ser potencialmente fiscalizado pelas redes sociais cibernéticas e confrontado pelo fluxo de informação que elas produzem, editam e articulam por meio das ferramentas de CMC. Talvez os usuários estejam, hoje, inseridos ou mais próximos do cenário prenunciado por Castells, em 2006, quando afirmou que, em pouco tempo, os movimentos sociais e os indivíduos em rebelião crítica iriam começar a agir sobre a grande mídia, a controlar as informações, a desmenti-las e a produzi-las conforme critérios próprios e por meio de um processo ininterrupto de colaboração. 


\section{NOTAS}

1 Consideramos como Sites de Rede Social as ferramentas digitais que proporcionam a construção de um perfil ou persona que represente o indivíduo na rede, a publicação da rede social dos usuários e, por fim, a interação entre eles (BOYD; ELLISON, 2007). Ao contrário do que possa parecer, os SRSs não compreendem a rede social em si, sendo apenas os sistemas que a suportam (RECUERO, 2009a).

2 O perfil da Folha de S. Paulo no Facebook pode ser acessado por meio do seguinte endereço: https://www.facebook.com/folhadesp?fref=ts

3 Postagem é o termo pelo qual as publicações dos usuários do Facebook costumam ser chamadas.

4 A ideia de laço social representa a efetiva conexão entre atores que estão envolvidos em interações. O laço, assim, pode ser considerado como o "resultado da sedimentação das relações estabelecidas entre agentes" (RECUERO, 2009a, p. 38).

5 A World Wide Web, também conhecida como WWW, é um sistema de documentos em hipermídia que são executados a partir da internet.

6 Meme é um termo que indica uma unidade de informação com capacidade de multiplicar-se, seja pela transmissão de uma pessoa a outra seja pelos locais onde é armazenada. A ideia de meme surgiu, em 1976, na obra de Richard Dawkins denominada The Selfish Gene e publicada no Brasil sob o título "O Gene Egoísta" (2007). Para o autor, o meme seria para a memória o análogo do gene para genética. Sendo assim, Dawkins (2007) considera que o meme é uma unidade de evolução cultural que pode se autopropagar, funcionando como replicador de comportamentos. Desse modo, ideias, línguas, sons, desenhos, valores ou qualquer outra coisa facilmente apreensível e, autonomamente, transmissível pode configurar-se como um meme.

7 Flash Mobs são aglomerações instantâneas de pessoas, em um local determinado previamente, que realizam ações e rapidamente se dispersam. O objetivo dos encontros é a realização de algum ato inusitado. As ações costumam ser organizadas pela troca de mensagens via internet.

8 A Experian Hitwise é a ferramenta líder global de inteligência digital da Experian Marketing Services.

9 O jornal Folha de S. Paulo foi criado em 1921. 
10 Segundo dados divulgados pelo grupo Folha e auditados pelo Instituto Verificador de Circulação (IVC) em outubro de 2012, a Folha é o jornal brasileiro com maior tiragem e circulação entre os diários de interesse geral. Os dados estão disponíveis no site da Folha (www.folha.uol.com.br/institucional).

11 No Facebook há um indicativo chamado "estão falando sobre isso", que visa demonstrar quanto um usuário e seus conteúdos são "discutidos" pelo resto da rede. A métrica que compõe tal indicativo leva em conta toda e qualquer história (postagem) no Facebook que envolva a marca ou o perfil em questão. Qualquer coisa que for compartilhada em um mural alheio é considerada.

12 Neste artigo, o termo Rede (grafado com R maiúsculo) deve ser entendido como uma referência à Rede Mundial de Computadores (internet).

13 O sistema do Facebook permite que seus usuários criem listas ou grupos de pessoas e compartilhem suas publicações de forma restrita a um desses grupos ou de maneira pública, tornando o conteúdo acessível a qualquer usuário do site.

14 O Facebook possibilita que os usuários limitem o acesso a cada uma de suas publicações, ou seja, elas podem ser públicas, restritas a um grupo determinado de pessoas ou particulares.

${ }^{15}$ Chamam-se de links externos os links que levam a qualquer material armazenado fora do sistema em que ele foi publicado.

16 Emoticons são formas de comunicação paralinguística que se formatam por meio de uma sequência de caracteres tipográficos, tais como: :), ou $\wedge-\wedge$, ou também, uma imagem que transmita o estado psicológico, emotivo, de quem os emprega. A palavra derivada da junção do termo inglês emotion (emoção) + o termo icon (ícone).

17 Segundo Raquel Recuero (2009), Capital Social é o conjunto de recursos de um determinado grupo que pode ser usufruído por todos os membros do grupo, ainda que individualmente, e que está baseado na reciprocidade. Ele está embutido nas relações sociais e é determinado pelo conteúdo delas. Ainda de acordo com a autora, os SRSs são capazes de construir e facilitar a emergência de tipos de capital que não são facilmente acessíveis aos atores sociais no espaço off-line.

18 Cabe destacar que quando se fala em colaboração não se está, necessariamente, falando de uma ação positiva. Assim, considera- 
se como colaborativo o comportamento que acrescenta e/ou corrige, esclarece uma informação independentemente do tom que a mensagem assuma dentro do contexto.

19 A definição de campo é dada por Pierre Bourdieu (1998) e aponta à observância de: 1) um "enjeu" ou "prêmio" disputado por diferentes agentes sociais, e 2) da existência de um grupo especializado que afirma possuir um monopólio de conhecimento especializado. A noção de campo, portanto , pode ser comparada à noção de "esfera de atividade" encontrada em Bakhtin e, no presente artigo, são consideradas como expressões análogas.

20 O Facebook permite que os usuários denunciem os comentários que não consideram adequados à rede e/ou que o removam de seu feed. Os conteúdos denunciados são analisados pelos administradores do SRS.

21 O chamado Feed de notícias - a coluna central da página inicial de cada usuário do Facebook - é uma lista em constante atualização de históricos de pessoas e páginas que cada usuário segue. As histórias do feed de notícias incluem atualizações de status, fotos, vídeos, links, atividade de aplicativos e opções "curtir".

22 Ombudsman é o nome dado ao profissional que, ao ser contratado por um veículo de mídia, faz críticas, expõe deficiências e aponta os erros cometidos pelo veículo e seus profissionais. Ele também pode sugerir mudanças e apontar possíveis soluções para os problemas identificados. Pelo caráter de seu trabalho, o ombudsman possui contrato de trabalho pré-fixado e, assim, pode atuar com total liberdade.

\section{REFERÊNCIAS}

BASTOS, M. T.; ZAGO, G. Visibilidade de notícias no Twitter e no facebook: Análise comparativa das notícias mais repercutidas na Europa e nas Américas. In: Brazilian Journalism Research. v. 9, n. 1. 2013. p. 116-133.

BOURDIEU, P. On Television. Nova York: The New Press, 1998.

BOYD, D.; ELLISON, N.. Social network sites: definition, history, and scholarship. In: Journal of Computer-Mediated Communication, 2007. Disponível em: <http://jcmc.indiana.edu/vol13/issuel/boyd. ellison.html>. Acesso em: 28 de setembro de 2010.

BRUNO, N. tweet first, verify later? How real-time information is 
changing the coverage of worldwide cirsis events. Oxford: Reuters Institute, 2011 . p. 77. Disponível em: <https://reutersinstitute.politics.ox.ac.uk/ fileadmin/documents/Publications/fellows_papers/2010-2011/TWEET_ FIRST_VERIFY_LATER.pdf $>$. Acesso em: 20 de maio de 2013.

BRUNS, A.; HIGHFIELD, T. Blogs, twitter, and Breaking News: The Produsage of Citizen Journalism. In: ANN LIND, R. (Org.). Produsing Theory in a Digital World: The Intersection of Audiences and Production. New York: Peter Lang, 2012. p. 15-32.

CÁDIMA, F. Das crises aos desafios do jornalismo na era pós-wikileaks. In.: CUNHA, I.; CABRERA, A.; SOUSA, J.P. (Org.). Pesquisa em media e jornalismo: homenagem a Nelson Traquina. Covilhã: Labcom, 2012. p. 234-253.

CASTELLS, M. A era da intercomunicação. Le Monde Diplomatique, Paris, $1^{\circ}$ de agosto de 2006, Biblioteca Virtual, Outro Mundo. Disponível em:< http://www.diplomatique.org.br/acervo.php?id=1915>. Acesso em: 27 de abril de 2010.

CASTELLS, M. A sociedade em rede. São Paulo: Paz e terra, 2010.

DALMASO, S. Uma fanpage para compartilhar links: a utilização do Facebook pelo jornal Diário de Santa Maria. In: Simpósio nacional da ABCiber, 6., Novo Hamburgo. 2012. Anais... Novo Hamburgo, RS: ABCiber, 2012.

DAWKINS, R. O Gene Egoísta. São Paulo: Companhia das Letras, 2007.

DOMINGUES, I. Netizens e prosumers: novas mídias, co-criação e consumerismo político. In: \#MídiasSociais: perspectivas, tendências e reflexões. Ebook Coletivo, 2010.

GLASER, B.; STRAUSS, A. L. The Discovery of Grounded Theory: Strategies for Qualitative Research. New York: Aldine de Gruyter, 1967.

GOMES, M. Jornalismo e ciências da linguagem. São Paulo: Hacker, 2000.

HERMIDA, A. Tweets and Truth: Journalism as a discipline of collaborative verification. Journalism Practice, v. 6, n. 5-6. 2012. p. 659-668.

JENKINS, H.; FORD, S.; GREEN, J. Spreadable Media. New York: NYU Press, 2013. p. 352.

JENKINS, H. Cultura da Convergência. São Paulo: Aleph, 2009.

JÚNIOR, F. Do papel ao Facebook: outras textualidades midiáticas no jornalismo da Folha de S. Paulo. Relêem, v. 6, n. 1. 2013.

LEMOS, A. Cibercultura. Porto Alegre: Sulina, 2004.

LEMOS, A. Ciber-cultura-remix. In: Seminário Sentidos e Processos. São 
Paulo: Itaú Cultural, 2005. Disponível em: http://tinyurl.com/2b5tjxy. Acesso em: 10 de janeiro de 2013.

LEMOS, A.; LÉVY, P. O futuro da internet: em direção a uma ciberdemocracia planetária. São Paulo: Paulus, 2010.

LÉVY, P. Cibercultura. São Paulo: 34, 1999.

O'BOYLE, L. The image of the journalist in France, Germany, and England, 1815-1848. In: Comparative Studies in Society and History. 1968. Disponível em: http://www.jstor.org/stable/177803. Acesso em: 13 de junho de 2010.

PENA, F. Jornalismo literário. São Paulo: Contexto, 2006.

PRIMO, A. Os Blogs Não São Diários Pessoais Online: Matriz Para Tipificação Da Blogosfera. Porto Alegre: Revista da Famecos, n. 36. 2008.

PRIMO, A. Transformações no jornalismo em rede: sobre pessoas comuns, jornalistas e organizações; blogs, Twitter, Facebook e Flipboard. Intexto. v. 2, n. 25. 2011 . p.130-146.

RECUERO, R. A Conversação em Rede. Porto Alegre: Sulina, 2012.

RECUERO, R.; FRAGOSO, S.; AMARAL, A. Métodos de Pesquisa para Internet. Porto Alegre: Sulina, 2011.

RECUERO, R. Redes Sociais na Internet. Porto Alegre: Sulina, 2009a.

RECUERO, R. Redes Sociais na Internet, Difusão de Informação e Jornalismo: Elementos para discussão. In: SOSTER, D. de A.; FIRMINO, F. (Org.). Metamorfoses jornalísticas 2: a reconfiguração da forma. Santa Cruz do Sul: UNISC, 2009b. p. 1-269.

SCHUDSON, M. Porque as notícias são como são. In: Revista de Comunicação e Linguagens, v. 8, 1988.

SCHUDSON, M. The power of news. Cambridge: Harvard Press, 1995.

TEIXEIRA, M. O. A construção do enunciado jornalístico no Twitter. 229f. Dissertação (mestrado). Pelotas: Universidade Católica de Pelotas, 2011. Disponível em: http://antares.ucpel.tche.br/poslet/dissertacoes/ Mestrado/2011/A\%2 0Constru\%E7\%E3o\%2 0do\%20Enunciado\%20 Jornalistico\%20no\%20Twitter\%20\%20Mabel\%200liveira\%20Teixeira.pdf. Acesso em: 30 mar. 2014.

TEIXEIRA, M. O Jornalismo no Twitter: uma conversa transformadora?. In: XIII Congreso Internacional Ibercom. 13., Santiago de Compostela, 2013. Anais... Santiago de Compostela: IBERCOM, AssIBERCOM, AGACOM, 2013. p. 3945-3955. 
TRAQUINA, N. Porque as notícias são como são. Florianópolis: Insular, 2005. (Teorias do jornalismo, v.1).

TRAQUINA, N. A tribo jornalística - uma comunidade interpretativa transnacional. Florianópolis: Insular, 2008. (Teorias do jornalismo, v. 2).

VIS, F. Twitter as a reporting tool for breaking news. Digital Journalism, v. 1, n. 1. 2012. p. 27-47.

ZAGO, G. Recirculação jornalística no Twitter: filtro e comentário de notícias por interagentes como uma forma de potencialização da circulação. 201. Dissertação (mestrado). Porto Alegre: Faculdade de Biblioteconomia e Comunicação, Universidade Federal do Rio Grande do Sul, 2011.

Mabel Oliveira Teixeira Doutoranda pelo Programa de Pós-Graduação em Letras da Universidade Católica de Pelotas com bolsa Fapergs/Capes. E-mail: mabel.ppg@gmail.com 